\title{
SANITASI DAN HYGIENE PADA PROSES PEMBUATAN RAMBAK IKAN BUNTAL PISANG (Tetraodon lunaris) DI UKM JAYA UTAMA KECAMATAN MAYANGAN KOTA PROBOLINGGO JAWA TIMUR
}

\author{
Rahyuni Syamsudin Domili \\ Program Studi Budidaya Perairan Fakultas Ilmu- Ilmu Pertanian, \\ Universitas Muhammadiyah Gorontalo \\ Email : youneerahyuni@gmail.com
}

\begin{abstract}
Sanitasi and hygiene condition of a food business determine the safety of the product. Sanitation is defined as disease prevention efforts by eliminating the environmental factors associated with disease transfer chain. While Hiygiene is the effort to control food-borne illnesses. The purpose of this study was to investigate the application of sanitary and hiygiene on banana puffer fish rambak (Tetraodon lunaris) in UKM Jaya Utama Mayangan Village Probolinggo, East Java. The method used in this research is a survey and deskriptif method, the technique of primary data collection is done through observation, documentation, interviews using questionnaires on sanitation and hygiene practices. The main raw material is the skin of banana puffer fish. Aspects of sanitation and hygiene was observed include sanitation and hygiene of raw materials, sanitation and hygiene of auxiliary materials, sanitation and hygiene water, sanitation and hygiene of workers, sanitation and hygiene of processing and environmental rooms as well as sanitation and hygiene of end products.
\end{abstract}

Keywords: Sanitasi, Hygiene, banana puffer fish rambak

\begin{abstract}
Abstrak
Kondisi sanitasi higiene suatu usaha pangan menentukan keamanan produk. Sanitasi diartikan sebagai usaha pencegahan penyakit dengan cara menghilangkan faktor- faktor lingkungan yang berkaitan dengan rantai perpindahan penyakit. Sedangkan hygiene adalah usaha pengendalian penyakit yang ditularkan melalui makanan. Penelitian ini bertujuan untuk mengkaji penerapan praktek sanitasi dan hygiene pada usaha pengolahan Rambak Ikan Buntal Pisang (tetraodon lunaris) di UKM Jaya Utama Kec. Mayangan Kota Probolinggo Jawa Timur. Metode yang digunakan dalam penelitian ini adalah metode deskriptif. Data diperoleh melalui observasi, dokumtasi dan wawancara menggunakan daftar pertanyaan terhadap praktek sanitasi dan hygiene. Bahan baku utama yang digunakan sebagai rambak adalah kulit ikan buntal pisang. Aspek sanitasi dan hygiene yang diamati antara lain sanitasi dan hygiene bahan baku, sanitasi dan hygiene bahan tambahan, sanitasi dan hygiene air, sanitasi dan hygiene pekerja, sanitasi dan hygiene ruang pengolahan dan lingkungan serta sanitasi dan hygiene produk akhir.
\end{abstract}

Kata kunci: Sanitasi, hygiene, rambak ikan buntal

\section{PENDAHULUAN}

Di Indonesia, ikan buntal pisang (Tetraodon lunaris) belum dioptimalkan secara maksimal karena ikan ini dianggap sebagai ikan beracun yang mematikan, padahal di perairan Indonesia ikan jenis ini cukup berlimpah. Racun ikan buntal adalah tetradotoksin yang terdapat di gonad, usus, hati, empedu, dan di bawah kulit. Dengan pengolahan yang tepat, daging ikan buntal menjadi sangat komersial. Tiap tahun, Jepang mengonsumsi ikan buntal jenis Fugu sebanyak 20.000 ton. Di Indonesia, ikan buntal dikonsumsi di daerah Pelabuhan Ratu,
Sukabumi, dan Tuban yang diolah menjadi ikan asin (Rukiyah et al., 2010).

Salah satu produk olahan yang dapat menggunakan bahan baku ikan buntal, terutama kulitnya yaitu rambak. Rambak berasal dari kulit yang dapat digunakan sebagai bahan dalam pembuatan kerupuk kulit ikan harus dalam kondisi yang memenuhi syarat baik dari segi kesegarannya, ketebalannya, dan keuletannya. Adapun kulit ikan mentah tersebut dapat diperoleh dalam keadaan basah maupun kering (Indraswari, 2003). 
UKM Jaya Utama yang terletak di Kota Probolinggo merupakan salah satu UKM yang mengolah berbagai macam produk olahan perikanan. Salah satunya rambak ikan buntal ini. Selain rambak ikan buntal UKM ini juga memproduksi keripik tulang ikan, otak- otak, nugget ikan dan lain- lain.

Salah satu faktor penting yang mendukung terciptanya keamanan pangan adalah kondisi sanitasi dan higiene pengolahan pangan. Praktek sanitasi higiene pengolahan pangan yang kurang baik dapat menimbulkan hal-hal yang merugikan konsumen, seperti keracunan makanan maupun penyakit yang ditularkan melalui makanan. Kasus keracunan pangan yang dilaporkan selama tahun 2004 berjumlah 7.347 kasus di 25 propinsi dan 45 orang di antaranya meninggal (BPOM-RI, 2005). Ditinjau dari sumber pangannya, maka penyebab keracunan pangan dari masakan rumah tangga sebanyak $47,1 \%$, industri jasa boga $22,2 \%$, dan makanan jajanan sebanyak $14,4 \%$. Hal ini mengindikasikan bahwa kesadaran masyarakat terhadap kebersihan dan higiene pengolahan pangan skala rumah tangga masih rendah.

Penerapan sanitasi higiene pada usaha pangan skala kecil atau rumah tangga di Indonesia umumnya masih jauh dari standar yang ditetapkan. Sanitation Standard Operating Procedures (SSOP) merupakan suatu prosedur untuk memelihara konsisi sanitasi yang umumnya berhubungan dengan seluruh fasilitas produksi atau area perusahaan dan tidak terbatas pada tahapan tertentu. Sanitasi merupakan cara pencegahan penyakit dengan mengatur atau menghilangkan faktorfaktor lingkungan yang saling terkait dalam rantai perpindahan penyakit tersebut. Oleh sebab itu peneliti ingin mengetahui penerapan aspek sanitasi dan hygiene di rambak ikan buntal di UKM Jaya Utama.

Hasil kajian diharapkan sebagai bahan sosialisasi dan pembinaan tentang cara pengolahan pangan yang baik dan benar untuk produsen/pekerja pengolahan ikan khuhusnya rambak ikan buntal dalam upaya meningkatkan kualitas produk olahan ikan.

\section{METODE PENELITIAN}

Penelitian ini dilaksanakan di UKM Utama Jaya Utama Kecamatan Mayangan Kota Probolinggo Jawa Timur pada bulan Maret hingga April 2012. Obyek penelitian ini berupa industri rumah tangga rambak buntal pisang dari bahan baku kulit ikan buntal pisang. Metode yang digunakan dalam penelitian ini adalah metode deskriptif. Data primer diperoleh dari pengamatan langsung di lokasi penelitian, dan wawancara dari karyawan maupun pemilik perusahaan. Data sekunder dapat diperoleh dari dokumentasi, pustaka dan arsip dari unit usaha perikanan yaitu pembuatan rambak ikan buntal pisang tersebut. Analisis data pada penelitian ini dilakukan secara kualitatif dan bersifat deskripstif.

\section{HASIL DAN PEMBAHASAN}

\section{Proses Pembuatan Rambak Ikan Buntal Pisang}

Proses pembuatan rambak ikan buntal merupakan serangkaian kegiatan penanganan yang dilakukan manusia dari bahan baku sampai menjadi suatu produk akhir yang siap dikonsumsi oleh manusia. Dalam pengolahan tahap kegiatannya dapat berupa penanganan awal, pengulitan, pencucian, penyimpanan dalam freezer box, perendaman dalam larutan bumbu, penjemuran, penghalusan duri dan pemotongan, penggorengan dan pengemasan. Diagram pembuatan rambak dapat dilihat pada Gambar 1.

\section{Sanitasi Dan Hygiene}

Sanitasi dan higiene merupakan salah satu cara atau prosedur dalam suatu unit pengolah ikan yang dapat menghasilkan produk yang aman dikonsumsi, karena sanitasi higiene merupakan standar kebersihan dan kesehatan yang harus dipenuhi agar dapat mencegah terjadinya kerusakan pada ikan tersebut dan akan menghasilkan mutu yang di inginkan (Lobura, 2010).

\section{Sanitasi dan Hygiene Bahan Baku}

Bahan baku yang digunakan dalam proses pembuatan rambak ikan buntal pisang yaitu ikan buntal pisang, secara umum belum ditangani dengan baik sesuai dengan standar sanitasi dan hygiene. Terbukti dari informasi diketahui ikan buntal pisang yang diangkut dari Tempat Pelelangan Ikan (TPI) dibawa menggunakan mobil pick up dengan menggunakan bak terbuka. Penggunaan bak terbuka tanpa tutup ini bisa menyebabkan debu dan kotoran mengkontaminasi bahan baku. 


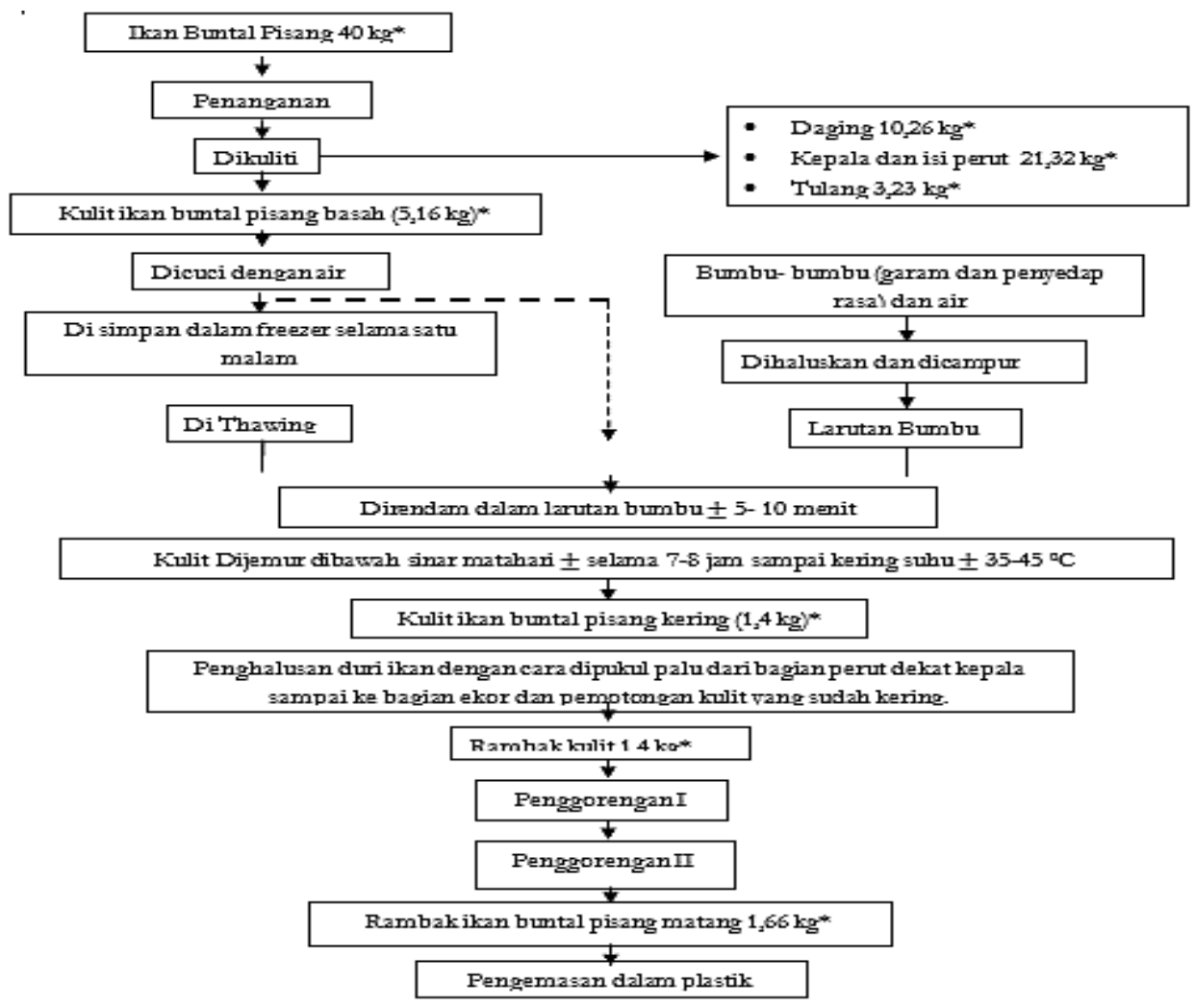

*Catatan : Angka-angka dihitung berdasarkan konversi dari 1 ekor ikan.

Gambar 1. Diagram alir proses pembuatan rambak ikan buntal pisang

Ditinjau dari sanitasi dan hygiene bahan yaitu ikan buntal cukup baik. Ikan yang diambil dari TPI masih dalam keadaan segar. Ikan yang segar menghasilkan kulit ikan buntal yang berkualitas baik. Menurut Lobura (2010), bahan baku merupakan faktor penting dalam menentukan produk akhir kerena mutu produk akhir ditentukan pula oleh mutu bahan baku yang digunakan. Bahan baku yang masuk kebagian produksi diteliti mutunya. Pengawasan mutu yang dilakukan melalui pengawasan organoleptik, meliputi warna, insang berwarna merah cerah, kulit masih elastis dan bau masih segar. Dalam proses penyiangan dan pengolahan bahan baku mulai insang, isi perut dan lendir yang menjadi sumber kontaminan dalam proses penyiangan semua itu dihilangkan dan diletakkan ke dalam keranjang plastik kemudian dicuci bersih. Namun penentuan kualitas bahan baku yang akan diolah tidak ada standar secara pasti. Semua ikan buntal pisang segar yang didapat langsung dilakukan proses pengulitan.

\section{Sanitasi dan Hygiene Bahan Tambahan}

Ditinjau dari segi sanitasinya, bahanbahan tambahan dalam produk rambak ikan buntal pisang tersebut sudah cukup baik.
Bahan-bahan tersebut hanya diletakkan pada wadah-wadah plastik dalam keadaan tertutup. Sehingga mengurangi terjadinya kontaminasi dengan komponen lain dari luar.

\section{Sanitasi dan Hygiene Air}

Air yang digunakan di UKM Jaya Utama sudah cukup bagus dan sesuai standar. Hal tersebut dikarenakan air yang berasal dari pompa cukup memenuhi standart air untuk minum atau juga pengolahan bahan pangan. Purnawijayanti (2001) berpendapat bahwa syarat air yang digunakan dalam pengolahan makanan antara lain: bebas dari bakteri berbahaya serta bebas dari ketidakmurnian kimiawi, bersih dan jernih, tidak berwarna dan tidak berbau, dan tidak mengandung bahan tersuspensi.

\section{Sanitasi dan Hygiene Pekerja}

Pada unit usaha pengolahan rambak ikan buntal pisang ini dikerjakan oleh 7 orang tenaga kerja. Ditinjau dari sanitasi dan hygiene pekerja nampaknya masih kurang memperhatikan kebersihan terhadap produk yang ditangani. Menurut Budiyono et al., (2009), tingkat pengetahuan sanitasi higiene pengolah pangan skala kecil di Indonesia 
adalah rendah, ditambahkan oleh Djarismawati et al., (2004), kondisi sanitasi higiene yang buruk tidak selalu berhubungan dengan tingkat pengetahuan sanitasi higiene pengolah pangan yang kurang memadai.

Dari pengamatan tidak ada pekerja yang menggunakan baju khusus atau celemek untuk bekerja saat mengolah rambak ikan buntal. Hal ini disebabkan pengolahan rambak ikan buntal ini dilakukan secara sederhana dan tradisional sehingga mereka menganggap lebih praktis menggunakan baju yang dipakai sehari- hari. Para pekerja belum menggunakan penutup kepala saat mengolah, beberapa pekerja lakilaki menggunakan topi sedangkan pekerja perempuan menggunakan jilbab.

Mencuci tangan dengan sabun sebelum melakukan kontak langsung dengan bahan baku sangat penting, sebagian pekerja ada yang mencuci tangan sebelum menyentuh bahan baku dan sebagian pekerja tidak mencuci tangan. Menurut Shojaei et al., (2006), mencuci tangan dengan sabun terbukti dapat mengurangi frekuensi kontaminasi mikroba pada tangan pengolah pangan di Iran dari $109(72,8 \%)$ menjadi 48 orang (32\%). Dari hasil wawancara ada sebagian pekerja yang sudah mengetahui pentingnya mencuci tangan sedangkan sebagian lagi kurang memperhatikan pentingnya mencuci tangan sebelum bekerja karena beranggapan tangan mereka tidak terkontaminasi atau sudah mencuci tangan sebelum berangkat dari rumah mereka.

Kondisi tempat yang sempit dan suasana yang panas menyebabkan pekerja banyak mengeluarkan keringat sehingga kemungkinan besar produk terkontaminasi oleh kotoran yang berasal dari pekerja. Dari pengamatan ada pekerja yang menggunakan sarung tangan kain akan tetapi sarung tangan tersebut terlihat kotor dan sering dipakai berulang, sehingga menyebabkan kontaminasi silang pada proses pengolahan rambak ikan buntal.

\section{Sanitasi dan Hygiene Ruang Pengolahan dan Lingkungan}

Sanitasi udara pada ruang produksi pembuatan rambak ikan buntal pisang UKM Jaya Utama cukup memenuhi syarat Ditinjau dari sirkulasi udara di dalam ruang produksi sudah lancar. Hal ini dikarenakan ventilasi di dalam ruang produksi sudah berfungsi dengan baik, sehingga udara didalam dapat cepat berganti namun terhindar dari debu dan kotoran dari luar ruangan. Menurut Sari
(2004), kondisi udara di daerah persiapan makanan tergantung banyak faktor yaitu adanya debu, tetesan air dan pergerakan udara yang terbawa oleh gerak angin dari ventilasi atau manusia yang bergerak. Tetesan air dari orang yang berbicara, batuk dan bersin dapat member mikroba dalam udara.

Sementara sanitasi bangunan dan lantai ruang produksi serta efektivitas bangunan sudah cukup baik. Dinding bangunan sudah terbuat dari tembok. Lantainya sudah dikeramik, yang dikontruksi mudah dibersihkan.

Berdasarkan pengamatan Letak lokasi UKM Jaya Utama berada dekat dari perkampungan penduduk, lingkungan kurang bersih, dan berada pada daerah yang dekat dari pencemaran seperti yang berasal dari sumber sampah, rawa, pemukiman padat dan sistem saluran air yang tidak baik.

\section{Sanitasi dan Hygiene Produk Akhir}

Pada produk akhir pengolahan rambak ikan buntal pisang, sanitasi dan hygienitas produk dirasa cukup. Hal tersebut dibuktikan dengan adanya perlakuan akhir produksi dan pengemasan yang terencana. Setelah rambak ikan buntal pisang digoreng, dilakukan proses pendinginan. Setelah dingin baru langsung dikemas. Hal tersebut bertujuan agar uap panasnya hilang sehingga kadar air produk benar-benar turun serta jika produk dikemas agar tidak berkeringat dan menimbulkan menurunnya daya simpan. Kemasan yang digunakan cukup aseptis yaitu menggunakan plastik PP yang diseal dengan mesin.

\section{KESIMPULAN}

Berdasarkan hasil penelitian aspek sanitasi dan hygiene yang dilaksanakan di Mayangan Kota Probolinggo, tentang proses pembuatan rambak ikan buntal pisang diperoleh; 1) bahan baku utama yang digunakan sebagai rambak adalah kulit ikan buntal pisang. 2) tahapan pada proses pembuatan rambak ikan buntal pisang adalah penanganan awal, pengulitan, pencucian, penyimpanan dalam freezer box, perendaman dalam larutan bumbu, penjemuran, penghalusan duri dan pemotongan, penggorengan dan pengemasan. Sacara umum, sanitasi dan hygiene diusaha pembuatan rambak buntal pisang ini belum memenuhi syarat, terutama untuk peralatan dan 
lingkungan. Sebelum digunakan dalam proses produksi, peralatan terlebih dahulu dicuci bersih. Saran yang dapat saya berikan pada UKM Jaya Utama yakni; 1) perlu ditingkatan lagi aspek kualitas dari produk sehingga produk yang dihasilkan lebih enak dan berkualitas. 2) alur produksi diperbaiki dan fasilitas-fasilitas produksi yang tidak dapat dipakai sebaiknya dilakukan perbaikan agar proses produksi dapat berjalan lebih lancar. 3) sebaiknya sanitasi pekerja harus diperhatikan mulai dari kesehatan, kebersihan dan lain sebagainya.

\section{DAFTAR PUSTAKA}

Budiyono, Junaedi $\mathrm{H}$, Isnawati, Wahyuningsih T. 2009. Tingkat pengetahuan dan praktik penjamah makanan tentang hygiene dan sanitasi makanan pada warung makan di Tembalang Kota Semarang tahun 2008. Jurnal Promosi Kesehatan Indonesia 4(1): 50-60.

Djarismawati B, Sukana, Sugiharti. 2004. Pengetahuan dan perilaku penjamah tentang sanitasi pengolahan makanan pada instalasi gizi rumah sakit di Jakarta. Media Litbang Kesehatan 14(3): 31-37.

Indraswari, C. S.E. 2003. Teknologi Pengolahan Pangan: Rambak Kulit Ikan. Kanisius. Yogyakarta. 97 halaman.

Lobura, P. 2010. Pengawasan Mutu Pada Proses Pembekuan Fillet Tuna (Thunnus Sp) Bentuk Saku di PT. Tridaya Eramina Bahari Jakarta Utara. Karya Ilmiah. Karya ilmiah praktek akhir. Jurusan teknologi halsil perikanan. Kementrian Kelautan Dan Perikanan Badan Pengembangan Sdm Kelautan Dan Perikanan Akademi Perikanan Sidoarjo. 79 halaman.
Nurjanah, R. Nitibaskara, dan E Madiah. 2005. Pengaruh Penambahan Bahan Pengikat Terhadap Karakteristik Fisik Otak-Otak Ikan Sapu-Sapu (Liposarcus pardalis). Buletin Teknologi Hasil Perikanan. Vol VIII Nomor 1 Tahun 2005. Halaman 110. Peranginangin, R., S. T, S., dan T. M. 1995. Pengaruh Jenis dan Konsentrasi Daging Ikan Terhadap Pengembangan Volumetrik, Kerenyahan dan rasa Kerupuk. Jurnal Penelitian Fakultas Perikanan. Universitas Brawijaya. Malang.12 halaman.

Purnawijayanti, H. A. 2000. Sanitasi Hygiene dan Keselamatan Kerja dalam Pengolahan Makanan. Kanisius. Yogyakarta. 105 halaman.

Rukiyah I, Steven, Vini O, Wulan D, Dan Zahidah. 2010. Karakteristik Morfologi Tingkat Kemunduran Mutu Dan Analisis Kadar Protein Ikan Buntal Pisang (Tetraodon Lunaris). Artikel. Departemen Teknologi Hasil Perairan Fakultas Perikanan Dan Ilmu Kelautan, Institut Pertanian Bogor. 2 halaman.

Sari, P. 2004. Sanitasi dan Hygiene Dalam Industri Pangan. Fakultas Teknologi Pertanian. Universitas Jember. Jember. Hal 1, 35 dan 108.

Shojaei H, Shooshtaripoor J, Amiri M. 2006. Efficacy of simple hand-washing in reduction of microbial hand contamination of Iranian food handlers. Food Research International 39: 525-52

Suryani, D. A. 2007. Kualitas Kerupuk Rambak Kulit Kambing Peranakan Etawah (Pe) Dan Peranakan Boer (Pb) Ditinjau Dari Kadar Air, Daya Kembang, Rasa Dan Kerenyahan. Laporan Skipsi. Program Studi Teknologi Hasil Ternak, Fakultas Peternakan Universitas Brawijaya, Malang. 75 halaman. 